Article

\title{
Physical Properties of Jatropha curcas L. Fruits and Seeds with Respect to Their Maturity Stage
}

\author{
Sebastian Romuli *, Shkelqim Karaj® and Joachim Müller® \\ Tropics and Subtropics Group (440e), Institute of Agricultural Engineering, University of Hohenheim, \\ 70599 Stuttgart, Germany; shkelqim_karaj@uni-hohenheim.de (S.K.); joachim.mueller@uni-hohenheim.de (J.M.) \\ * Correspondence: info440e@uni-hohenheim.de or Sebastian_Romuli@uni-hohenheim.de; \\ Tel.: +49-711-459-23114
}

Received: 24 March 2019; Accepted: 26 April 2019; Published: 30 April 2019

check for updates

\begin{abstract}
Jatropha curcas L. is a multipurpose bioenergy crop. Physical properties of J. curcas fruits and seeds are a fundamental knowledge required for the design of processing machinery. Therefore, this research investigates the physical properties at different maturity stages as indicated by pericarp color of the fruits (green, yellow, and black). Rupture force, hardness, deformation at rupture point, deformation ratio at rupture, and energy used for rupture were measured in the length and width direction of the fruits and in the length, width, and thickness of the seeds. During the course of maturing, a decrease in the unit mass and the surface area of the fruits was observed with a simultaneous increase for the seeds. Moisture content decreased during maturing. Bulk density and solid density were considerably different among maturity stages. The lowest porosity was observed in black fruits as well as "black" seeds. The highest dynamic and static angle of repose was detected for black fruits, while no substantial difference was observed between "yellow" and "black" seeds. The highest and lowest coefficient of static friction for all fruits and seeds was found on rubber and plastic surfaces.
\end{abstract}

Keywords: detachment force; diameter; geometric characteristics; mechanical properties; physic nut; size

\section{Introduction}

Biodiesel is a renewable energy source produced from oil-bearing crops, which is gaining attention due to low emission profiles and environmental benefits [1]. With regard to the topic of "food vs. fuel", biodiesel production from non-edible oil crops such as Pongamia pinnata, Azadirachtra indica, and Jatropha curcas L. (J. curcas) has been primarily promoted [2,3]. Among all the crops, biodiesel production from $J$. curcas oil is rapidly growing, due to the high oil yield and long productive period of the crop $[4,5]$. As a drought-resistant crop with the adaptability to grow on marginal soils, the cultivation is becoming favorable in developing countries due to its contribution to rural development [4,6,7]. However, postharvest technology of $J$. curcas still requires a vast amount of research [8].

Hulling of the fruits [9] and shelling of the seeds [10] are considered essential mechanical postharvest processes to provide kernels (shelled seeds) as the main product [11], along with fruit hulls and seed shells as byproducts [7]. The byproducts are also a valuable oil-free biomass with a great potential for use as solid biofuels $[12,13]$. Physical properties of J. curcas fruits and seeds are a crucial baseline information to design, construct, and develop the adequate machineries. Subsequently, an efficient postharvest process can be accomplished by processing the appropriate fruits and seeds $[8,14]$.

Several studies have been conducted regarding the physical properties of J. curcas. Pradhan, et al. [15] examined the changes of physical properties in J. curcas fruits at different moisture contents. Physical properties of J. curcas vary considerably depending on biological and environmental factors [14]. Samsuri 
and Zoveidavianpoor [16] reported that the fully matured seeds can generate a $2.5 \%$ higher oil yield with better quality than those not fully matured. Also, the oil quality is strongly depending on the maturity stage [17]. Maturity stage of J. curcas fruits can be determined based on the color change of their pericarp from green via yellow to black [18]. It is to be expected that moisture content, geometric characteristics, bulk, and mechanical properties, as well as sliding friction characteristics are naturally altered during maturing. To the best of our knowledge, no studies have been published that explicitly investigated the effect of maturity stage on the physical properties of J. curcas fruits and seeds, in relation to engineering aspects. Therefore, this study aims to contribute to closing this knowledge gap, in order to enable the development of suitable machines for fruit and seed processing.

\section{Material and Methods}

\subsection{Material}

The experiments were conducted at a J. curcas plantation of the Federal Rural University of Rio de Janeiro, Seropedica, Brazil. The fruits were collected from a research plantation of the university $\left(-22.763084{ }^{\circ} \mathrm{N},-43.696592{ }^{\circ} \mathrm{E}\right)$, where the annual precipitation ranges from 1000 to $1300 \mathrm{~mm}$. The ambient temperature during the harvest time in February 2014 was $22.6^{\circ} \mathrm{C}$. About $20 \mathrm{~kg}$ of J. curcas fruits from each maturity stage were randomly picked, and on the same day, the experiments were conducted at a laboratory of the University.

The fruits were sorted manually based on their pericarp color. From each stage, the fruits were hulled manually to obtain the seeds. It was observed that the majority of the green fruits had either very small seeds or none at all. Therefore, the seeds of green fruits were irrelevant and not included in this study. Seeds from yellow and black fruits are addressed as "yellow" and "black" in this study, even though both of them had a dark pericarp color. See Figure 1.
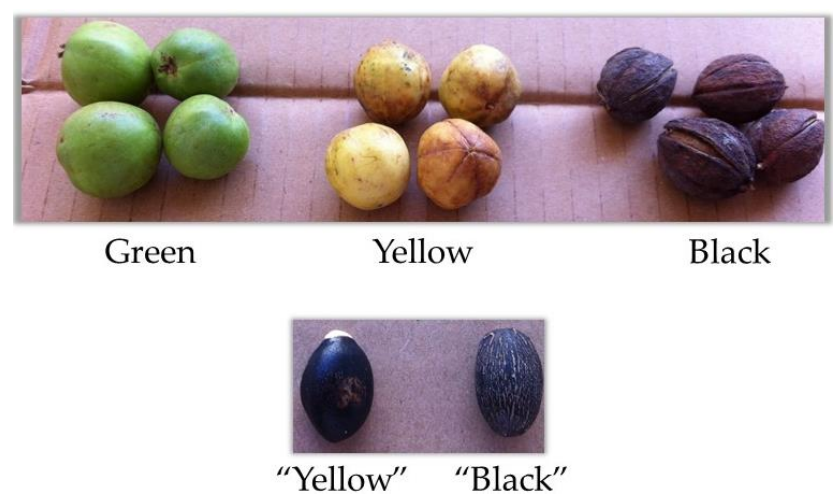

Figure 1. Classification of J. curcas fruits and seeds according to the pericarp color of the fruits.

\subsection{Detachment Force for Harvesting the Fruits}

Detachment force $F_{Z}(\mathrm{~N})$ was estimated by tying a rope to a digital force gauge (HDB 5k5, Kern and Sohn $\mathrm{GmbH}$, Balingen, Germany) to a fruit and drawing it vertically until the fruit detached from the branch. The force was noted, and the measurement was replicated five times.

\subsection{Moisture Content, Geometric Characteristics, and Bulk Properties}

Moisture content $M(\%)$ was determined using a convection oven (UM 700, Memmert GmbH \& Co. KG, Schwabach, Germany) according to DIN CEN/TS 14774-3 [19] in five replicates, whereas five J. curcas fruits and seeds per replicate from each maturity stage were taken. In order to determine the unit mass and the geometrical characteristics, $20 \mathrm{~J}$. curcas fruits and seeds were randomly picked from each maturity stage. Unit mass $m$ (g) was measured using a digital balance (AY220, Shimadzu Co., Kyoto, Japan). Length $L(\mathrm{~mm})$, width $W(\mathrm{~mm})$, and thickness $T(\mathrm{~mm})$ were determined according to Pradhan, Naik, Bhatnagar, and Vijay [15] for J. curcas fruits, and according to Karaj and Müller [14] 
for the seeds. The dimensions were measured using a Vernier digital caliper (Mitutoyo Corporation, Kawasaki, Japan) with an accuracy of $\pm 0.01 \mathrm{~mm}$. Sphericity $\varphi$, arithmetic diameter $D_{a}(\mathrm{~mm})$, geometric diameter $D_{g}(\mathrm{~mm})$, unit volume $V_{u}\left(\mathrm{~cm}^{3}\right)$, surface area $S\left(\mathrm{~mm}^{2}\right)$, and specific surface area $S_{s}\left(\mathrm{~cm}^{2} / \mathrm{cm}^{3}\right)$ of the fruits and the seeds were estimated according to Karaj and Müller [14].

Bulk density $\rho_{b}\left(\mathrm{~g} / \mathrm{cm}^{3}\right)$ was determined by filling the material into a two-liter container, weighing the total mass, and calculating as:

$$
\rho_{b}=\frac{m_{T}-m_{E}}{V}
$$

where $m_{T}$ is the total mass of the filled container $(\mathrm{g}), m_{E}$ is the net mass of the empty container $(\mathrm{g})$, and $V$ is the volume of the container $\left(\mathrm{cm}^{3}\right)$.

Solid density $\rho_{s}\left(\mathrm{~g} / \mathrm{cm}^{3}\right)$ was calculated by dividing the unit mass of the material with its true volume [14]. Porosity $\varepsilon$ was estimated from bulk density and solid density according to Mohsenin [20]. Each measurement was conducted in five replicates.

A hele-Shaw cell, $300 \mathrm{~mm}$ wide and $200 \mathrm{~mm}$ high, consisting of a timber scaffold as frame and covered by transparent acrylic glass, was used to determine the static angle of repose $\theta_{s}\left({ }^{\circ}\right)$ by constantly adding the material from the top of the cell. The slope formed by the pile of the material was measured using a digital inclinometer (gm 09, Scheppach $\mathrm{GmbH}$, Ichenhausen, Germany) with an accuracy of $\pm 0.01^{\circ}$.

The formation of the dynamic angle of repose $\theta_{d}\left({ }^{\circ}\right)$ was measured by filling a bottomless plastic cylinder, with $220 \mathrm{~mm}$ diameter and $260 \mathrm{~mm}$ height and lifting it vertically. Each measurement was carried out in five replicates. The angle was calculated as:

$$
\theta=\tan ^{-1} \cdot \frac{2 \cdot h}{d}
$$

where $h$ stands for height $(\mathrm{mm})$ and $d$ for diameter $(\mathrm{mm})$ of the container.

\subsection{Determination of Mechanical Properties}

In order to determine the mechanical properties, $20 \mathrm{~J}$. curcas fruits and seeds per replicate from each maturity stage were randomly taken. Rupture force $F_{R}(\mathrm{~N})$ and deformation at rupture point, $R_{D P}(\mathrm{~mm})$ were measured using a compression tester (UMC-300, Contenco Ind. And Com. LTDA, São José da Lapa, Brazil) in the direction of length $(x)$, width $(y)$ and thickness $(z)$ in five replicates, as illustrated in Figure 2. Ratio between $F_{R}$ and $R_{D P}$ was calculated as hardness $H(\mathrm{~N} / \mathrm{mm})$. BlueHill2 software (Instron $\AA$, Massachusetts, USA) was utilized to record the data. Deformation ratio at rupture point $R_{D R}$ was estimated as the ratio between $R_{D P}$ and the dimension of a fruit or seed $(L, W$, or $B)$. Energy for rupture $E_{R}(\mathrm{~N} \mathrm{~mm})$ was calculated by the measurement device.
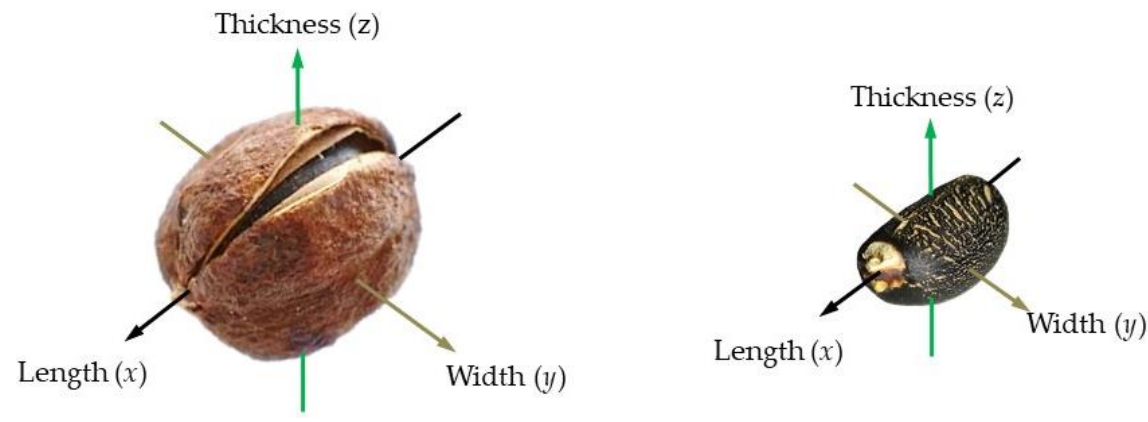

Figure 2. Loading directions for a J. curcas fruit (left) and seed (right).

\subsection{Sliding Friction Characteristics}

The measurement of coefficient of static friction $\mu$ was conducted by filling the material into a bottomless wooden frame, with dimensions of $200 \times 200 \times 150 \mathrm{~mm}$, and pulling it over various surface materials such as polyvinyl chloride (PVC), steel type 1.0037 (S235JR), plywood, and chloroprene rubber. 
The force for initiating the motion was quantified using a digital force gauge (HDB 5k5, Kern and Sohn $\mathrm{GmbH}$, Balingen, Germany). Each measurement was conducted in five replicates. The calculation was done as:

$$
\mu=\frac{F_{T}-F_{E}}{W_{T}}
$$

where $\mu$ is the coefficient of static friction, $W_{T}$ is the total weight of the filled container $(\mathrm{N}), F_{T}$ is the force to pull the filled container $(\mathrm{N})$, and $F_{E}$ is the force to pull the empty container $(\mathrm{N})$.

\subsection{Statistical Analysis}

Mean values and standard deviation were reported in this study. The graphs were drawn using OriginPro 9.0 (OriginLab Corp, Massachusetts, USA). Data were analyzed based on least significant difference (LSD) test using SAS 9.0 (SAS Inc, North Carolina, USA).

\section{Results and Discussion}

\subsection{Detachment Force at Different Maturity Stages}

Detachment force of J. curcas fruits at different maturity stages is presented in Figure 3 . The highest detachment force was measured for green fruits with $9.09 \mathrm{~N}$, and was lowest for yellow fruits with only $3.14 \mathrm{~N}$. This might be due to the physiological changes during fruit maturing. However, the detachment force of black fruits was significantly higher with $5.03 \mathrm{~N}$ than for yellow fruits at $p<0.05$, which might be due to the drying of the fruit stalk, leading to a loss of elasticity. These findings are important for the mechanical harvesting operations, such as different shaking frequencies based on the maturity stages of the fruits [21,22]. In general, all the fruits had a lower detachment force than yellow J. curcas fruits from Malaysia (16.62 N) as reported by Yahya, Hamdan, Ishola, and Suryanto [23].

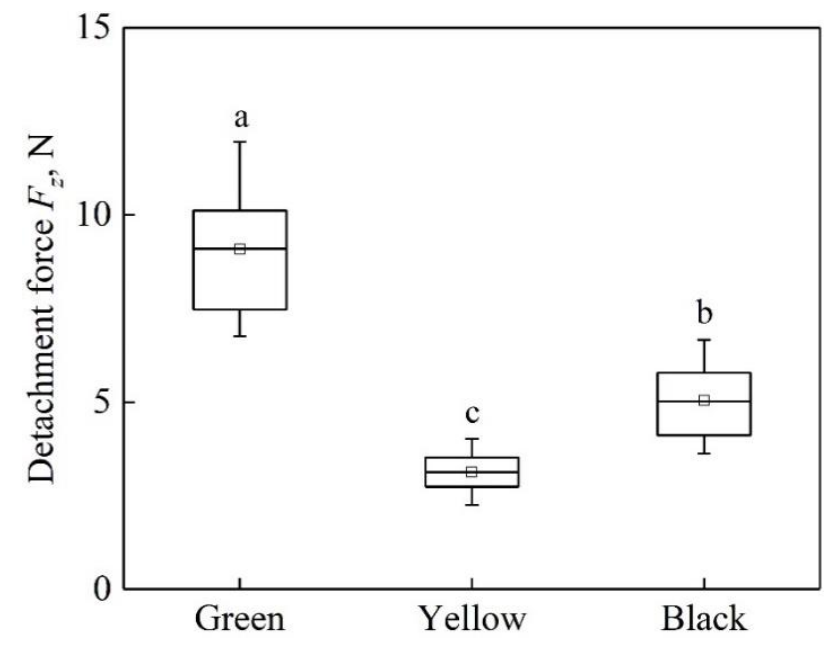

Figure 3. Detachment force of J. curcas fruit at different maturity stages. Different small letters (a, b, and c) indicate significant differences at $p<0.05$.

\subsection{Geometric Characteristics of J. curcas Fruits and Seeds}

Geometric properties of J. curcas fruits and seeds from each maturity stage are presented in Table 1. 
Table 1. Moisture content and geometric characteristics of J. curcas fruits and seeds at different maturity stages.

\begin{tabular}{|c|c|c|c|c|c|c|c|c|c|c|c|}
\hline Fraction & $\begin{array}{l}\text { Moisture } \\
\text { Content } \\
(\%)\end{array}$ & $\begin{array}{l}\text { Unit Mass } \\
\text { (g) }\end{array}$ & $\begin{array}{l}\text { Length } L \\
\text { (mm) }\end{array}$ & $\begin{array}{l}\text { Width } W \\
\text { (mm) }\end{array}$ & $\begin{array}{c}\text { Thickness } T \\
\text { (mm) }\end{array}$ & $\begin{array}{c}\text { Sphericity } \\
\varphi\end{array}$ & $\begin{array}{l}\text { Arithmetic } \\
\text { Diameter } D_{a} \\
(\mathrm{~mm})\end{array}$ & $\begin{array}{l}\text { Geometric } \\
\text { Diameter } D_{g} \\
(\mathrm{~mm})\end{array}$ & $\begin{array}{l}\text { Volume } V_{u} \\
\left(\mathrm{~cm}^{3}\right)\end{array}$ & $\begin{array}{l}\text { Surface } \\
\text { Area } S \\
\left(\mathrm{~mm}^{2}\right)\end{array}$ & $\begin{array}{c}\text { Specific } \\
\text { Surface } \\
\text { Area } S_{s} \\
\left(\mathrm{~cm}^{2} / \mathrm{cm}^{3}\right)\end{array}$ \\
\hline \multicolumn{12}{|l|}{ Fruits } \\
\hline Green & $85.2^{\mathrm{a}} \pm 1.1$ & $8.23^{\mathrm{a}} \pm 0.28$ & $26.61^{\mathrm{a}} \pm 0.33$ & $25.71^{\mathrm{a}} \pm 0.32$ & $26.38^{a} \pm 0.30$ & $0.99^{\mathrm{a}} \pm 0.01$ & $26.23^{\mathrm{a}} \pm 0.29$ & $26.22^{\mathrm{a}} \pm 0.29$ & $9.50^{\mathrm{a}} \pm 0.31$ & $2164^{\mathrm{a}} \pm 47$ & $1.2^{\mathrm{b}} \pm 0.04$ \\
\hline Yellow & $79.5^{\mathrm{b}} \pm 3.6$ & $5.25^{\mathrm{b}} \pm 0.27$ & $24.64^{\mathrm{b}} \pm 0.34$ & $24.55^{\mathrm{b}} \pm 0.25$ & $25.14^{\mathrm{b}} \pm 0.34$ & $0.98^{\mathrm{a}} \pm 0.02$ & $24.78^{\mathrm{b}} \pm 0.28$ & $24.77^{\mathrm{b}} \pm 0.27$ & $8.00^{\mathrm{b}} \pm 0.26$ & $1931^{b} \pm 42$ & $1.4^{\mathrm{b}} \pm 0.07$ \\
\hline $\begin{array}{l}\text { Black } \\
\text { Seeds }\end{array}$ & $8.6^{c} \pm 0.5$ & $2.51^{\mathrm{c}} \pm 0.11$ & $26.90^{\mathrm{a}} \pm 0.38$ & $21.99^{c} \pm 0.21$ & $24.59^{b} \pm 0.27$ & $0.91^{\mathrm{b}} \pm 0.01$ & $24.50^{\mathrm{b}} \pm 0.24$ & $24.40^{\mathrm{b}} \pm 0.24$ & $7.64^{\mathrm{b}} \pm 0.22$ & $1873^{b} \pm 36$ & $1.6^{\mathrm{a}} \pm 0.07$ \\
\hline "Yellow" & $58.3^{\mathrm{a}} \pm 5.5$ & $0.41^{\mathrm{b}} \pm 0.03$ & $16.98^{b} \pm 0.14$ & $10.56^{\mathrm{a}} \pm 0.21$ & $8.17^{\mathrm{a}} \pm 0.07$ & $0.67^{\mathrm{a}} \pm 0.01$ & $11.90^{\mathrm{b}} \pm 0.09$ & $11.30^{\mathrm{b}} \pm 0.13$ & $0.77^{\mathrm{b}} \pm 0.02$ & $468^{\mathrm{b}} \pm 11$ & $4.5^{\mathrm{a}} \pm 0.31$ \\
\hline “Black" & $6.8^{\mathrm{b}} \pm 0.5$ & $0.57^{\mathrm{a}} \pm 0.02$ & $18.33^{\mathrm{a}} \pm 0.12$ & $10.78^{a} \pm 0.11$ & $8.32^{\mathrm{a}} \pm 0.07$ & $0.64^{\mathrm{a}} \pm 0.00$ & $12.48^{\mathrm{a}} \pm 0.09$ & $11.80^{\mathrm{a}} \pm 0.09$ & $0.87^{\mathrm{a}} \pm 0.02$ & $503^{a} \pm 9$ & $4.1^{\mathrm{a}} \pm 0.19$ \\
\hline
\end{tabular}

Different letters within groups (fruits, seeds) in a column indicate significant differences at $p<0.05$. Mean values \pm standard deviation. 


\subsubsection{Fruits}

The results showed that moisture content, unit mass, and dimensions of green fruits were considerably higher than for yellow and black fruits. The large width and thickness indicate a thick layer of moist flesh in the fruit hulls at this maturity stage. As the fruits were maturing, the unit mass decreased from 8.23 to $2.51 \mathrm{~g}$, the surface area decreased from 2164 to $1873 \mathrm{~mm}^{2}$, and the specific surface area escalated from 1.2 to $1.6 \mathrm{~cm}^{2} / \mathrm{cm}^{3}$. The dimensions of yellow fruits, such as length, width, and thickness were slightly smaller than those of yellow J. curcas fruits from Malaysia investigated by Yahya, Hamdan, Ishola, and Suryanto [23], but similar to the ones from Thailand [24]. Regardless of the pericarp color, the shape of J. curcas fruits was detected as spherical, since the sphericity of all maturity stages was higher than 0.7 [25]. Compared to black J. curcas fruits from India [15], the surface area of the black fruits was similar, width and thickness were higher, and the length was substantially lower.

\subsubsection{Seeds}

The moisture content of "yellow" seeds was significantly higher than for "black" seeds, while the unit mass was lower at $p<0.05$. Only "black" seeds were suitable for oil extraction, since the proper moisture content of J. curcas seeds for the process should be below $10 \%$ [26,27]. Based on these findings, an overview of the moisture and oil content of J. curcas seeds has been established to maximize the oil yield. Moreover, the lower moisture content of "black" seeds could result in a longer shelf life and higher resistance against mold, fungi, and other contaminants. On the other hand, the dimensions of "black" seeds, such as length, width, thickness, arithmetic diameter, geometric diameter, volume, and surface area were generally larger than for "yellow" seeds. With increasing maturity of the fruits, the size of the seeds increased and the moisture content decreased [18]. As the seeds were maturing, the unit mass increased from 0.4 to $0.6 \mathrm{~g}$, the surface area increased from 467.6 to $503.3 \mathrm{~mm}^{2}$, and the specific surface area dropped from 4.5 to $4.1 \mathrm{~cm}^{2} / \mathrm{cm}^{3}$. Only the specific surface area of "black" seeds was slightly lower than for "yellow" seeds. Therefore, these results indicated that "yellow" seeds were not mature enough for harvest and could cause low oil yield during mechanical oil extraction due to their high moisture and low oil content. Due to its sphericity, the shape of J. curcas seeds was identified as ellipsoid [14]. It can also be seen that "yellow" seeds had a higher proportion of shells (61.9\%) than "black" seeds (45.8\%).

The unit mass and the geometric characteristics of "yellow" and "black" seeds were lower than in J. curcas seeds from Thailand [24], but similar to J. curcas seeds from India [14]. Moreover, the moisture content of "black" seeds seemed in good agreement with the J. curcas seeds from India.

\subsection{Bulk Properties as Affected by Different Maturity Stages}

Bulk density, solid density, porosity, and dynamic and static angle of repose of J. curcas fruits and seeds at different maturity stages are presented in Table 2.

Table 2. Bulk characteristics of J. curcas fruits and seeds at different maturity stages.

\begin{tabular}{cccccc}
\hline Fraction & $\begin{array}{c}\text { Bulk Density } \\
\rho_{b}\left(\mathbf{g} / \mathbf{c m}^{3}\right)\end{array}$ & $\begin{array}{c}\text { Solid Density } \\
\rho_{s}\left(\mathbf{g} / \mathbf{c m}^{\mathbf{3}}\right)\end{array}$ & Porosity $\epsilon \mathbf{( \% )}$ & $\begin{array}{c}\text { Dynamic Angle of } \\
\text { Repose } \boldsymbol{\theta}_{\boldsymbol{d}}\left({ }^{\circ}\right)\end{array}$ & $\begin{array}{c}\text { Static Angle of } \\
\text { Repose } \boldsymbol{\theta}_{\boldsymbol{s}}\left({ }^{\circ}\right)\end{array}$ \\
\hline Fruits & & & & & \\
Green & $0.45^{\mathrm{a}} \pm 0.006$ & $0.88^{\mathrm{a}} \pm 0.038$ & $45.4^{\mathrm{a}} \pm 1.06$ & $23.8^{\mathrm{c}} \pm 1.11$ & $26.9^{\mathrm{c}} \pm 1.16$ \\
Yellow & $0.35^{\mathrm{b}} \pm 0.003$ & $0.66^{\mathrm{b}} \pm 0.340$ & $41.6^{\mathrm{a}} \pm 0.55$ & $27.2^{\mathrm{b}} \pm 1.25$ & $29.6^{\mathrm{b}} \pm 0.44$ \\
Black & $0.21^{\mathrm{c}} \pm 0.003$ & $0.30^{\mathrm{c}} \pm 0.013$ & $25.5^{\mathrm{b}} \pm 1.81$ & $29.8^{\mathrm{a}} \pm 1.32$ & $32.7^{\mathrm{a}} \pm 0.78$ \\
Seeds & & & & & \\
"Yellow" & $0.32^{\mathrm{b}} \pm 0.002$ & $0.59^{\mathrm{a}} \pm 0.076$ & $49.9^{\mathrm{a}} \pm 0.36$ & $34.7^{\mathrm{a}} \pm 1.2$ & $37.5^{\mathrm{a}} \pm 0.79$ \\
"Black" & $0.42^{\mathrm{a}} \pm 0.006$ & $0.65^{\mathrm{a}} \pm 0.021$ & $45.4^{\mathrm{b}} \pm 0.54$ & $32.9^{\mathrm{a}} \pm 1.1$ & $36.7^{\mathrm{a}} \pm 0.61$ \\
\hline
\end{tabular}

Different letters within groups (fruits, seeds) in a column indicate significant differences at $p<0.05$. Mean values \pm standard deviation. 


\subsubsection{Fruits}

The results revealed that green fruits had a higher bulk density, solid density, and porosity than yellow and black fruits. Black fruits exhibited a significantly higher dynamic and static angle of repose, but also a lower bulk density, solid density, and porosity than the other fruits at $p<0.05$. A decrease of porosity from $45.4 \%$ to $25.5 \%$ was detected when the fruits were maturing. Regarding the dynamic and static angle of repose, black fruits are expected to have a lower flowability than yellow and green ones. The angle of repose indicates the flowability, which is related to cohesion among the fruits [15].

Bulk density, solid density, and porosity of yellow fruits were generally smaller than those of the variety "Kanlueang" from Thailand [24]. The properties of black fruits such as bulk density, solid density, porosity, and dynamic angle of repose were also lower than those of fruits from India [15].

\subsubsection{Seeds}

The results revealed that "black" seeds showed a relatively higher bulk density and solid density than "yellow" seeds. Porosity of "yellow" seeds was substantially higher than for "black" seeds at $p<0.05$. No significant difference of static and dynamic angle of repose was identified between "yellow" and "black" seeds at $p<0.05$.

The porosity of "yellow" and "black" seeds was higher than for J. curcas seeds from India, as reported by Karaj and Müller [14], but lower than for J. curcas seeds from Thailand as reported by Sirisomboon, Kitchaiya, Pholpho, and Mahuttanyavanitch [24]. Both angles of repose were lower than those of J. curcas seeds from Thailand, but similar to the J. curcas seeds from India.

\subsection{Effect of Maturity Stage on Mechanical Properties}

Mechanical properties of J. curcas fruits and seeds from different maturity stages, such as rupture force, hardness, energy for rupture, deformation, and deformation ratio at rupture point are presented in Table 3. The results clearly show that a substantial divergence of mechanical properties was observed among the maturity stages of both fruits and seeds, when forces were applied in different directions.

\subsubsection{Fruits}

Due to the high sphericity of $J$. curcas fruits at all maturity stages $(>0.90)$, the properties from width and thickness were similar. Therefore, in this study, mechanical properties of the fruits were determined only for their width and length. In the $x$-direction, green fruits had the highest rupture force, while the lowest hardness was identified for yellow fruits at $p<0.05$. On the other hand, rupture force and hardness of black fruits in the $y$-direction were substantially higher than for the other fruits at $p<0.05$. No significant difference in energy expenditure for the rupture was observed in the of length and width directions for all fruits at $p<0.05$. Moreover, it can also be seen that the deformation at rupture point and the deformation ratio at rupture force of black fruits were considerably lower in both directions than for green and yellow fruits. Rupture force and hardness of yellow fruits $(98.1 \mathrm{~N}$ and $12.5 \mathrm{~N} / \mathrm{mm}$ ) was lower than for J. curcas yellow fruits from Thailand (135.4 N and $30.6 \mathrm{~N} / \mathrm{mm}$ ), as reported by Sirisomboon, Kitchaiya, Pholpho, and Mahuttanyavanitch [24]. On the other hand, rupture force and hardness of the black fruits in their width $(149.9 \mathrm{~N}$ and $33.3 \mathrm{~N} / \mathrm{mm})$ were similar to those of the yellow fruits from Thailand. Nevertheless, no information on the loading direction was reported in their study. 
Table 3. Mechanical properties of $J$. curcas fruits and seeds at different maturity stages.

\begin{tabular}{|c|c|c|c|c|c|}
\hline Fraction & Rupture Force $F_{R}(\mathrm{~N})$ & Hardness $H(\mathrm{~N} / \mathrm{mm})$ & $\begin{array}{c}\text { Energy for Rupture } E_{R} \\
(\mathrm{~N} \mathrm{~mm})\end{array}$ & $\begin{array}{l}\text { Deformation at Rupture } \\
\text { Point } R_{D P}(\mathrm{~mm})\end{array}$ & $\begin{array}{l}\text { Deformation Ratio at } \\
\text { Rupture Force } R_{D R}\end{array}$ \\
\hline \multicolumn{6}{|c|}{$x$-direction (Length) } \\
\hline \multicolumn{6}{|l|}{ Fruits } \\
\hline Green & $84.0^{\mathrm{a}} \pm 14.37$ & $15.6^{\mathrm{ab}} \pm 2.14$ & $209.7^{\mathrm{a}} \pm 50.47$ & $4.9^{\mathrm{ab}} \pm 0.59$ & $0.19^{a} \pm 0.02$ \\
\hline Yellow & $56.7^{b} \pm 12.46$ & $10.8^{b} \pm 2.54$ & $201.1^{\mathrm{a}} \pm 81.39$ & $5.5^{\mathrm{a}} \pm 1.52$ & $0.21^{\mathrm{a}} \pm 0.06$ \\
\hline Black & $51.4^{\mathrm{b}} \pm 10.52$ & $26.0^{\mathrm{a}} \pm 16.18$ & $99.3^{\mathrm{a}} \pm 80.45$ & $2.9^{b} \pm 1.62$ & $0.10^{b} \pm 0.06$ \\
\hline \multicolumn{6}{|l|}{ Seeds } \\
\hline "Yellow" & $99.6^{\mathrm{a}} \pm 33.85$ & $63.3^{\mathrm{b}} \pm 16.39$ & $71.5^{a} \pm 36.85$ & $1.6^{\mathrm{a}} \pm 0.41$ & $0.09^{\mathrm{a}} \pm 0.02$ \\
\hline “Black" & $113.2^{\mathrm{a}} \pm 35.32$ & $91.5^{\mathrm{a}} \pm 22.94$ & $64.6^{\mathrm{a}} \pm 27.97$ & $1.3^{\mathrm{a}} \pm 0.43$ & $0.07^{\mathrm{a}} \pm 0.02$ \\
\hline \multicolumn{6}{|c|}{$y$-direction (Width) } \\
\hline \multicolumn{6}{|l|}{ Fruits } \\
\hline Green & $108.3^{\mathrm{ab}} \pm 15.46$ & $14.2^{\mathrm{b}} \pm 3.22$ & $476.0^{\mathrm{a}} \pm 137.84$ & $7.9^{\mathrm{a}} \pm 1.80$ & $0.34^{\mathrm{a}} \pm 0.08$ \\
\hline Yellow & $98.1^{\mathrm{b}} \pm 26.18$ & $12.5^{\mathrm{b}} \pm 5.79$ & $322.5^{\mathrm{a}} \pm 57.13$ & $8.7^{a} \pm 2.01$ & $0.36^{\mathrm{a}} \pm 0.09$ \\
\hline Black & $149.9^{\mathrm{a}} \pm 39.02$ & $33.3^{\mathrm{a}} \pm 7.78$ & $327.8^{\mathrm{a}} \pm 99.57$ & $4.5^{\mathrm{b}} \pm 0.69$ & $0.21^{b} \pm 0.03$ \\
\hline \multicolumn{6}{|l|}{ Seeds } \\
\hline "Yellow" & $44.9^{\mathrm{a}} \pm 14.26$ & $71.3^{\mathrm{b}} \pm 18.18$ & $19.2^{\mathrm{a}} \pm 11.19$ & $0.7^{\mathrm{a}} \pm 0.23$ & $0.06^{\mathrm{a}} \pm 0.02$ \\
\hline "Black" & $46.0^{a} \pm 9.06$ & $96.0^{\mathrm{a}} \pm 14.04$ & $12.6^{\mathrm{a}} \pm 4.78$ & $0.5^{\mathrm{b}} \pm 0.09$ & $0.05^{\mathrm{a}} \pm 0.01$ \\
\hline \multicolumn{6}{|c|}{ z-direction (Thickness) } \\
\hline \multicolumn{6}{|l|}{ Seeds } \\
\hline "Yellow" & $89.5^{\mathrm{a}} \pm 36.78$ & $74.2^{\mathrm{a}} \pm 34.90$ & $62.4^{\mathrm{a}} \pm 30.75$ & $1.3^{\mathrm{a}} \pm 0.28$ & $0.15^{\mathrm{a}} \pm 0.04$ \\
\hline “Black" & $101.1^{\mathrm{a}} \pm 31.81$ & $90.4^{\mathrm{a}} \pm 20.40$ & $65.6^{\mathrm{a}} \pm 31.43$ & $1.1^{\mathrm{a}} \pm 0.26$ & $0.13^{\mathrm{a}} \pm 0.03$ \\
\hline
\end{tabular}

Different letters within groups (fruits, seeds) in a column for different directions (length, width, thickness) indicate significant differences at $p<0.05$. Mean values \pm standard deviation. 


\subsubsection{Seeds}

The results showed that the mechanical properties of "yellow" and "black" seeds in the thickness direction showed no significant differences at $p<0.05$. No substantial difference was detected in all directions between "yellow" and "black" seeds at $p<0.05$ for the rupture force. The lowest rupture force and energy for rupture were detected in the $y$-direction for both seeds. Similar results were obtained for J. curcas seeds from India, as investigated by Karaj and Müller [14]. In all directions, the hardness of "black" seeds was higher than that of "yellow" seeds. The highest hardness of $96.0 \mathrm{~N} / \mathrm{mm}$ was observed for "black" seeds in the $y$-direction. The differences of energy for rupture, deformation at rupture point, and deformation ratio at rupture force between "yellow" and "black" seeds, in the length and thickness direction, was insignificant at $p<0.05$. The rupture force of "yellow" seeds was lower than that for J. curcas "yellow" seeds from Thailand as reported by Sirisomboon, Kitchaiya, Pholpho, and Mahuttanyavanitch [24], but the hardness was similar to the seeds from Thailand. Moreover, rupture force, hardness, and energy for rupture of "black" seeds was generally lower than for J. curcas seeds from India, as reported by Karaj and Müller [14].

\subsection{Coefficient of Static Friction on Different Surface Materials}

Figure 4 exhibits the coefficient of static friction of J. curcas fruits and seeds, which was determined on different surface materials, such as plastic, metal, plywood, and rubber. On the same surface material, coefficient of static friction varied significantly among all the maturity stages of the fruits at $p<0.05$ but was not considerably different between the maturity stages of the seeds. Generally, the results revealed that rubber and plastic were the surface materials that generated the highest and lowest static friction, respectively.
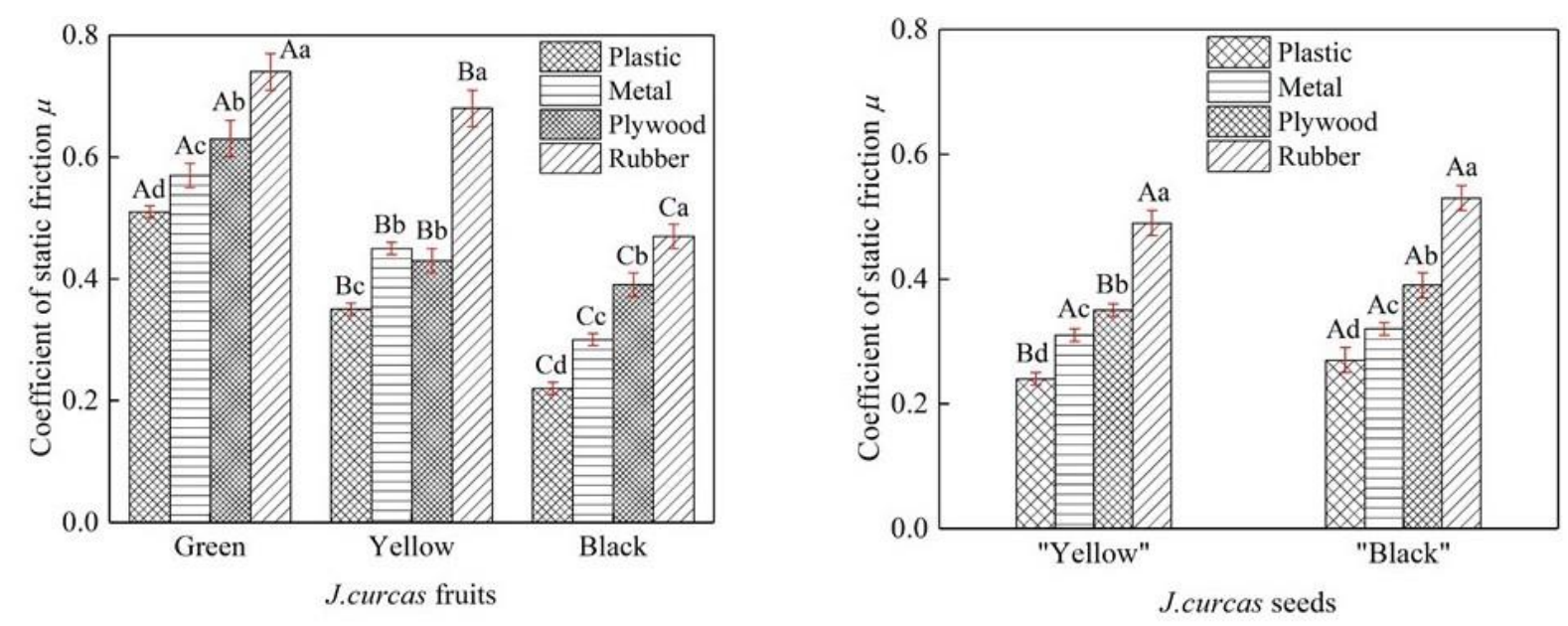

Figure 4. Coefficient of static friction of J. curcas fruits (left) and seeds (right) determined on different surface materials at different maturity stages. Uppercase letters indicate significant differences among the maturity stages, and lowercase letters indicate differences among the surface materials at $p<0.05$, respectively.

\subsubsection{Fruits}

The highest and lowest coefficient of static friction was observed for green fruits on rubber (0.74) and plastic (0.22), respectively. On the same surface material, black fruits showed a lower coefficient of static friction than green and yellow fruits. For all maturity stages, the highest and lowest coefficient of static friction was observed on rubber and plastic surfaces, respectively. Coefficient of static friction of yellow fruits on plywood with a value of 0.35 was slightly lower than for J. curcas yellow fruits from Malaysia [23] with a value of 0.48 and from Thailand [24] with a value of 0.50 . On metal surfaces, coefficient of static friction of yellow fruits was lower than for the yellow J. curcas fruits from Malaysia (0.58) and Thailand (0.64). 


\subsubsection{Seeds}

The highest and lowest coefficient of static friction was observed on rubber and plastic materials for "yellow" (0.49 and 0.24) and "black" (0.53 and 0.27) seeds, respectively. On the same surface material, no significant difference of coefficient of static friction was detected between "yellow" and "black" seeds at $p<0.05$. Similar results were obtained by Karaj and Müller [14] for J. curcas seeds from India.

\section{Conclusions}

The characteristics of J. curcas fruits and seeds at different maturity stages, as indicated by pericarp color, have been explored. The findings from this study are important to construct adequate equipment for J. curcas fruit hulling and seed shelling. The results show a substantial difference of geometrical characteristics, bulk properties, mechanical properties, and coefficient of static friction among the maturity stages of the fruits and the seeds. These differences could lead to different machine settings and dimensioning. Moreover, the findings of this study will be helpful in designing and constructing new machines. Detachment force of J. curcas fruits provides technical information to determine the vibration properties required by the harvesting machine. The maturity of J. curcas fruits and seeds can be clearly identified from their unit mass, moisture, and oil content. Of all the pericarp colors, black fruits and "black" seeds are the most suitable stage to achieve an optimum hulling and shelling process. The moderate detachment force and relatively low rupture force of black fruits could lead to a low energy requirement during processing, while the low moisture content of "black" seeds could result in a higher oil yield from mechanical oil extraction. Due to the high variability depending on location and genotype, research on the physical properties of J. curcas fruits and seeds from other cultivars and proveniences should be continued.

Author Contributions: Conceptualization, S.R., S.K., and J.M.; data curation, S.R. and S.K.; formal analysis, S.R.; funding acquisition, S.K. and J.M.; investigation, S.R.; methodology, S.K.; project administration, J.M.; resources, J.M.; supervision, S.K. and J.M.; validation, S.R.; visualization, S.R.; writing一original draft preparation, S.R.; writing-review and editing, S.K. and J.M.

Funding: This research was conducted within the project JatroilProtein 033R069A funded by the German Federal Ministry of Education and Research (BMBF), Berlin, Germany.

Acknowledgments: The authors would like to thank Alexandre Miguel do Nascimento, Universidade Federal Rural do Rio de Janeiro (UFRRJ) for technical support, and Gwendolin Krauss and Dino Tomazic (University of Hohenheim) for their field work as exchange students in Brazil.

Conflicts of Interest: The authors declare no conflict of interest.

\section{Abbreviations}

$D_{a} \quad$ Arithmetic diameter

$D_{g} \quad$ Geometric mean diameter

$d \quad$ Diameter of container

$E_{R} \quad$ Energy for rupture

$F_{E} \quad$ Force to pull the empty container

$F_{R} \quad$ Rupture force

$F_{T} \quad$ Force to pull the filled container

$F_{Z} \quad$ Detachment force

$H \quad$ Hardness

$h \quad$ Height of container

L Length

M Moisture content

$m \quad$ Unit mass

$m_{E} \quad$ Net mass of empty container

$m_{T} \quad$ Total mass of filled container

$\mu \quad$ Coefficient of static friction

$\mathrm{mm}$
$\mathrm{mm}$
$\mathrm{mm}$
$\mathrm{N} \mathrm{mm}$
$\mathrm{N}$
$\mathrm{N}$
$\mathrm{N}$
$\mathrm{N}$
$\mathrm{N} / \mathrm{mm}$
$\mathrm{mm}$
$\mathrm{mm}$
$\%$
$\mathrm{~g}$
$\mathrm{~g}$
$\mathrm{~g}$
-

$\mathrm{mm}$

$\mathrm{N} \mathrm{mm}$

$\mathrm{N}$

$\mathrm{mm}$

$\mathrm{mm}$

$\%$

g 


$\begin{array}{lll}\varphi & \text { Sphericity } & - \\ \theta_{s} & \text { Static angle of repose } & \circ \\ \theta_{d} & \text { Dynamic angle of repose } & \circ \\ \rho_{b} & \text { Bulk density } & \mathrm{g} / \mathrm{cm}^{3} \\ \rho_{s} & \text { Solid density } & \mathrm{g} / \mathrm{cm}^{3} \\ R_{D P} & \text { Deformation at rupture point } & \mathrm{mm} \\ R_{D R} & \text { Deformation ratio at rupture point } & - \\ S & \text { Surface area } & \mathrm{mm}^{2} \\ T & \text { Thickness } & \mathrm{mm}^{2} \\ S_{s} & \text { Specific surface area } & \mathrm{cm}^{2} / \mathrm{cm}^{3} \\ V & \text { Volume of container } & \mathrm{cm}^{3} \\ V_{u} & \text { Unit volume } & \mathrm{cm}^{3} \\ W & \text { Width } & \mathrm{mm}^{3} \\ W_{T} & \text { Total weight of filled container } & \mathrm{N} \\ x & \text { Direction of length } & \\ y & \text { Direction of width } & \\ z & \text { Direction of thickness } & \end{array}$

\section{References}

1. Ma, F.; Hanna, M.A. Biodiesel production: A review. Bioresour. Technol. 1999, 70, 1-15. [CrossRef]

2. Banković-Ilić, I.B.; Stamenković, O.S.; Veljković, V.B. Biodiesel production from non-edible plant oils. Renew. Sustain. Energy Rev. 2012, 16, 3621-3647. [CrossRef]

3. Borugadda, V.B.; Goud, V.V. Biodiesel production from renewable feedstocks: Status and opportunities. Renew. Sustain. Energy Rev. 2012, 16, 4763-4784. [CrossRef]

4. Ong, H.C.; Mahlia, T.M.I.; Masjuki, H.H.; Norhasyima, R.S. Comparison of palm oil, Jatropha curcas and Calophyllum inophyllum for biodiesel: A review. Renew. Sustain. Energy Rev. 2011, 15, 3501-3515. [CrossRef]

5. Achten, W.M.J.; Verchot, L.; Franken, Y.J.; Mathijs, E.; Singh, V.P.; Aerts, R.; Muys, B. Jatropha bio-diesel production and use. Bioresour. Technol. 2008, 32, 1063-1084. [CrossRef]

6. Achten, W.M.J.; Maes, W.H.; Aerts, R.; Verchot, L.; Trabucco, A.; Mathijs, E.; Singh, V.P.; Muys, B. Jatropha: From global hype to local opportunity. J. Arid. Environ. 2010, 74, 164-165. [CrossRef]

7. Contran, N.; Chessa, L.; Lubino, M.; Bellavite, D.; Roggero, P.P.; Enne, G. State-of-the-art of the Jatropha curcas productive chain: From sowing to biodiesel and by-products. Ind. Crops Prod. 2013, 42, 202-215. [CrossRef]

8. Lim, B.Y.; Shamsudin, R.; Baharudin, B.T.H.T.; Yunus, R. A review of processing and machinery for Jatropha curcas L. fruits and seeds in biodiesel production: Harvesting, shelling, pretreatment and storage. Renew. Sustain. Energy Rev. 2015, 52, 991-1002. [CrossRef]

9. Pradhan, R.C.; Naik, S.N.; Bhatnagar, N.; Vijay, V.K. Design, development and testing of hand-operated decorticator for Jatropha fruit. Appl. Energy 2010, 87, 762-768. [CrossRef]

10. Lim, B.Y.; Shamsudin, R.; Yunus, R. Development and testing of a Jatropha fruit shelling process for shell-free kernel recovery in biodiesel production. Biosystems Eng. 2014, 121, 46-55. [CrossRef]

11. King, A.J.; He, W.; Cuevas, J.A.; Freudenberger, M.; Ramiaramanana, D.; Graham, I.A. Potential of Jatropha curcas as a source of renewable oil and animal feed. J. Exp. Bot. 2009, 60, 2897-2905. [CrossRef]

12. Kratzeisen, M.; Müller, J. Suitability of Jatropha seed shells as fuel for small-scale combustion units. Renew. Energy 2013, 51, 46-52. [CrossRef]

13. Sharma, D.K.; Pandey, A.K.; Lata. Use of Jatropha curcas hull biomass for bioactive compost production. Biomass Bioenergy 2009, 33, 159-162. [CrossRef]

14. Karaj, S.; Müller, J. Determination of physical, mechanical and chemical properties of seeds and kernels of Jatropha curcas L. Ind. Crops Prod. 2010, 32, 129-138. [CrossRef]

15. Pradhan, R.C.; Naik, S.N.; Bhatnagar, N.; Vijay, V.K. Moisture-dependent physical properties of jatropha fruit. Ind. Crops Prod. 2009, 29, 341-347. [CrossRef]

16. Samsuri, A.; Zoveidavianpoor, M. Does the maturity of Jatropha curcas L. affect the quality and quantity of the yield of oil for biodiesel production? Int. J. Green Energy 2014, 11, 193-205. [CrossRef] 
17. Ramanadane, T.; Narayanan, A.L. Effect of different stages of fruit maturity and size grading on seed quality in jatropha (Jatropha curcas). Indian J. Agric. Sci. 2014, 84, 1558-1560.

18. Dranski, J.A.L.; Pinto Jr, A.S.; Steiner, F.; Zoz, T.; Malavasi, U.C.; Malavasi, M.M.; Guimarães, V.F. Physiological maturity of seeds and colorimetry of fruits of Jatropha curcas L. Revista Brasileira de Sementes 2010, 32, 158-165. [CrossRef]

19. DIN CEN/TS 14774-3. Determination of moisture content - oven dry method. In Part 3: Moisture in General Analysis Sample; Deutsches Institut für Normung e.V: Berlin, Germany, 2004.

20. Mohsenin, N.N. Physical Properties of Plant and Animal Materials; Gordon and Breach Science Publishers: New York, NY, USA, 1980; Volume 31, p. 891.

21. Ghani, M.N.A.; Hudzari, R.M.; Wahab, F.I.A.; Ramli, M.R.H.; Azhar, A.W.M. Design, construction and evaluation of a smart agricultural harvester. In Proceedings of the 2013 International Conference on MEMS and Mechanics, MEMSM 2013, Wuhan, China, 15-16 March 2013; Volume 705, pp. 487-492.

22. Ramli, M.R.H.; Ghani, M.N.A.; Razali, M.H.; Wahab, F.I.A.; Ngah, N. Determination of vibration properties of Jatropha curcas for mechanical harvesting operations. Songklanakarin J. Sci. Technol. 2012, 34, 9-15.

23. Yahya, A.; Hamdan, K.; Ishola, T.A.; Suryanto, H. Physical and mechanical properties of Jatropha curcas L. fruits from different planting densities. J. Appl. Sci. 2013, 13, 1004-1012.

24. Sirisomboon, P.; Kitchaiya, P.; Pholpho, T.; Mahuttanyavanitch, W. Physical and mechanical properties of Jatropha curcas L. fruits, nuts and kernels. Biosystems Eng. 2007, 97, 201-207. [CrossRef]

25. Dutta, S.K.; Nema, V.K.; Bhardwaj, R.K. Physical properties of gram. J. Agric. Eng. Res. 1988, 39, $259-268$. [CrossRef]

26. Savoire, R.; Lanoisellé, J.L.; Vorobiev, E. Mechanical Continuous Oil Expression from Oilseeds: A Review. Food Bioprocess Technol. 2013, 6, 1-16. [CrossRef]

27. Karaj, S.; Müller, J. Optimizing mechanical oil extraction of Jatropha curcas L. seeds with respect to press capacity, oil recovery and energy efficiency. Ind. Crops Prod. 2011, 34, 1010-1016. [CrossRef]

(C) 2019 by the authors. Licensee MDPI, Basel, Switzerland. This article is an open access article distributed under the terms and conditions of the Creative Commons Attribution (CC BY) license (http://creativecommons.org/licenses/by/4.0/). 